\title{
KERAGAMAN DAN KEKERABATAN KULTIVAR JAGUNG (Zea mays L.) LOKAL ASAL PULAU KISAR KABUPATEN MALUKU BERDASARKAN KARAKTER FENOTIP
}

\author{
Hermalina Sinay ${ }^{1}$, Estri Laras Arumingtyas ${ }^{2}$, Nunung Harijati ${ }^{2}$, Serafinah Indriyani ${ }^{2}$ \\ ${ }^{1}$ Program Studi Pendidikan Biologi FKIP Unpatti, Ambon \\ 2 Jurusan Biologi FMIPA, Universitas Brawijaya, Malang
}

E-mail: herlinbio@yahoo.co.id

\begin{abstract}
Background: The relationship of plant kinship can be done through the identification of the phenotype character that is the character that appears on the individual or plant organism that can be both quantitative and qualitative. The purpose of this research is to know the diversity and kinship of corn cultivar from Kisar Island Regency of Maluku Southwest of Maluku Province based on phenotype character.

Methods: The genetic material used was six local corn cultivars and one comparative variety. The six local corn cultivars are Red ruby with a brown cob, Blood red corn, Sticky, Ripe yellow, Deep yellow, and White, while the varieties are Srikandi varieties. To know the effect of cultivars and corn varieties on phenotypic diversity, variant analysis with Statistica Analytical System (SAS version 9.0) was used. To know the character that gives the greatest contribution to the diversity of cultivar phenotype and corn varieties, the main component analysis is done. To know the kinship among corn cultivars based on phenotypic character, gross analysis (cluster analysis) with hierarchy method is performed. The main component analysis and gameplay analysis was performed using SPSS version 18.0 computer program.

Results: The results of variance analysis showed a significant effect of maize cultivar on phenotypic diversity. Characters that contribute to the diversity of the corn cultivar phenotype are the proline level, the weight of cobs without harvesting at harvest, the weight of cobs without dryness of the oven, the weight of the cobs at $12 \%$ moisture content, the unleaded cobs at $12 \%$, the diameter of the ear, the number of seeds per ear, the number of rows of beans per ear, the number of leaves, and the length of the leaf. The results of Euclidean and Euclidean girder analysis show that the local yellow cultivars are in one group alone and have a low similarity with other local corn cultivars as well as the Srikandibased varieties based on their phenotypic characters.

Conclusion: There is a variety of phenotypes of local corn cultivars and varieties of Srikandi compounds grown on Kisar Island of Southwest Maluku Maluku Province.
\end{abstract}

Keywords: Diversity, Kinship, Cultivar, Kisar Corn, Phenotype Character.

\begin{abstract}
Abstrak
Latar Belakang: Hubungan kekerabatan tanaman dapat dilakukan melalui identifikasi terhadap karakter fenotip yaitu karakter yang nampak pada individu atau organisme tanaman yang dapat bersifat kuantitatif maupun kualitatif. Tujuan penelitian adalah untuk mengetahui keragaman dan kekerabatan kultivar jagung dari Pulau Kisar Kabupaten Maluku Barat Daya Provinsi Maluku berdasarkan karakter fenotip.

Metode: Bahan genetik yang digunakan adalah enam kultivar jagung lokal dan satu varietas pembanding. Keenam kultivar jagung lokal tersebut adalah kultivar Merah Delima Tongkol Cokelat, Merah Darah, Pulut, Kuning Genjah, Kuning Dalam, dan Putih, sedangkan varietas pembanding adalah varietas Srikandi. Untuk mengetahui pengaruh kultivar dan varietas jagung terhadap keragaman fenotip dilakukan analisis varian dengan program Statistica Analytical System (SAS versi 9.0). Untuk mengetahui karakter yang memberikan kontribusi paling besar terhadap keragaman fenotip kultivar dan varietas jagung, dilakukan analisis komponen utama. Untuk mengetahui kekerabatan di antara kultivar jagung berdasarkan karakter fenotip, dilakukan analisis gerombol (analisis cluster) dengan metode hirarki. Analisis komponen utama dan analisis gerombol dilakukan menggunakan program komputer SPSS versi 18.0.
\end{abstract}


Hasil: Hasil analisis varian menunjukkan adanya pengaruh nyata kultivar jagung terhadap keragaman fenotip. Karakter yang memberikan kontribusi keragaman fenotip kultivar jagung adalah kadar prolin, bobot tongkol tanpa kelobot saat panen, bobot tongkol tanpa kelobot kering udara, bobot tongkol tanpa kelobot kering oven, bobot tongkol pada kadar air $12 \%$, hasil tongkol tanpa kelobot pada kadar air $12 \%$, diameter tongkol, jumlah biji per tongkol, jumlah baris biji per tongkol, jumlah daun, dan panjang daun. Hasil analisis gerombol dan jarak Euclidean menunjukkan bahwa kultivar lokal Kuning berada pada satu kelompok sendiri dan memiliki kemiripan yang rendah dengan kultivar jagung lokal yang lain serta varietas pembanding Srikandi berdasarkan pada karakter fenotipnya.

Kesimpulan: Terdapat keragaman fenotip kultivar-kultivar jagung lokal dan varietas pembanding Srikandi yang ditanam di Pulau Kisar Kabupaten Maluku Barat Daya Provinsi Maluku.

Kata Kunci: Keragaman, Kekerabatan, Kultivar, Jagung Kisar, Karakter Fenotip.

\section{PENDAHULUAN}

Pulau Kisar merupakan salah satu daerah di Kabupaten Maluku Barat Daya Provinsi Maluku yang memiliki keragaman plasma nutfah jagung yang tinggi (Pesireron, dkk. 2013a). Di daerah ini, jagung diusahakan sebagai komoditi utama, dan selalu ditanam pada setiap kegiatan bercocok tanam dan pada semua musim tanam (Pesireron, dkk. 2013a). Sebelumnya, eksplorasi dan dokumentasi plasma nutfah jagung telah dilakukan oleh Alfons dkk. (2003), dan menemukan bahwa di Pulau Kisar Kabupaten Maluku Barat Daya, terdapat tujuh kultivar jagung lokal yang merupakan kultivar spesifik yaitu (1) kultivar merah delima tongkol cokelat, (2) merah delima tongkol putih, (3) merah darah, (4) lokal pulut putih, (5) pulut, (6) kuning genjah dan (7) kuning dalam. Sifat yang sangat menyolok dari kultivar-kultivar lokal ini adalah beragamnya warna pada bijinya. Diduga, bahwa kultivar-kultivar lokal ini memiliki kemampuan adaptasi terhadap kondisi lingkungan setempat.

Adanya kultivar lokal dengan karakteristik yang khas, dan kemampuan adaptasi yang tinggi merupakan kekayaan plasma nutfah yang harus dijaga kelestariannya, sehingga sifat tertentu yang dimiliki dapat dimanfaatkan untuk perakitan varietas unggul. Pabendon et al., (2008) menyatakan bahwa untuk keberhasilan program pemuliaan tanaman berupa pemilihan induk atau tetua, maka faktor yang sangat berperan penting adalah perakitan varietas, dan informasi hubungan kekerabatan di antara materi pemuliaan. Menurut Susantidiana (2009) persilangan di antara tetua yang berkerabat jauh akan menghasilkan keturunan yang segregasinya luas, sehingga memudahkan dalam memilih varietas yang diinginkan.

Analisis terhadap hubungan kekerabatan tanaman dapat dilakukan melalui identifikasi terhadap karakter fenotip yaitu karakter yang nampak pada individu atau organisme tanaman yang dapat bersifat kuantitatif maupun kualitatif. Penelitian mengenai hubungan kekerabatan berdasarkan karakter fenotipik pada tanaman jagung telah dilaporkan oleh banyak peneliti (Wijayanto, 2007; Febriani, dkk, 2008; Amzeri, dkk, 2011; Yusran dan Maemunah, 2011).

Untuk jagung dari Kabupaten Maluku Barat Daya, studi keragaman genetik berdasarkan karakteristik fenotip telah dilaporkan oleh Pesireron dkk. (2013a), serta di Kecamatan Leti dan Pulau - Pulau Terselatan (Pesireron, dkk, 2013b). Namun demikian hasil yang diperoleh belum menunjukkan clustering/pengelompokkan dalam bentuk dendogram yang menunjukkan posisi/hubungan keeratan antara kultivar-kultivar jagung lokal, tetapi hanya mengeksplorasi penampilan morfologi kultivar jagung yang ditemukan di Kabupaten Maluku Barat Daya.

Meskipun penelitian tentang hubungan kekerabatan terhadap jagung di Indonesia dengan menggunakan karakter fenotip/morfologi sudah banyak dilakukan, tetapi khusus untuk jagung dari Pulau Kisar sama sekali belum dilakukan penelitian khususnya terhadap keragaman dan kekerabatan di antara kultivar-kultivar jagung lokal di daerah tersebut berdasarkan pada sifat-sifat atau karakter fenotip. Tujuan penelitian ini adalah untuk mengetahui keragaman dan kekerabatan kultivar jagung dari Pulau Kisar Kabupaten 
Maluku Barat Daya Provinsi Maluku berdasarkan karakter fenotip.

\section{MATERI DAN METODE ENELITIAN}

Bahan genetik yang digunakan adalah enam kultivar jagung lokal dan satu varietas pembanding. Keenam kultivar jagung lokal tersebut adalah kultivar Merah Delima Tongkol Cokelat, Merah Darah, Pulut, Kuning Genjah, Kuning Dalam, dan Putih, sedangkan varietas pembanding adalah varietas Srikandi yang diperoleh dari Balai Penelitian Tanaman Serealia Maros Sulawesi Selatan. Penanaman jagung dilakukan di Desa Wonreli Pulau Kisar pada Bulan Desember 2013- Maret 2014.

Penelitian dilakukan menurut rancangan acak kelompok dengan tiga ulangan. Pengamatan terhadap karakter fenotip meliputi karakter pertumbuhan, karakter fisiologi, karakter stomata daun, dan karakter hasil. Karakter pertumbuhan meliputi tinggi tanaman, jumlah daun, panjang daun, dan lebar daun. Karakter fisiologi meliputi kadar prolin daun, umur berbunga jantan, umur berbunga betina, dan anthesis silking interval. Karakter anatomi daun meliputi jumlah stomata, kerapatan stomata, indeks stomata dan panjang porus stomata. Karakter hasil meliputi bobot tongkol tanpa kelobot saat panen, bobot tongkol tanpa kelobot kering udara, bobot tongkol tanpa kelobot kering oven, kadar air tongkol tanpa kelobot saat panen, bobot tongkol tanpa kelobot pada kadar air $12 \%$, panjang tongkol, diameter tongkol, jumlah biji per tongkol, jumlah baris biji per tongkol, dan hasil tongkol pada kadar air 12\%. Pengamatan terhadap karakter pertumbuhan, anatomi daun, dan fisiologi berupa kadar prolin daun dilakukan saat tanaman berumur 65 hari setelah tanam. Pengamatan terhadap karakter fisiologi lainnya berupa umur berbunga jantan, umur berbunga betina, dan anthesis silking interval dilakukan setelah terbentuknya bunga jantan dan bunga betina, sedangkan pengamatan terhadap karakter hasil dilakukan saat panen.

Data hasil pengamatan merupakan rata-rata dari tiga ulangan. Data yang diperoleh dianalisis menggunakan analisis sidik ragam untuk mengetahui pengaruh kultivar dan varietas jagung terhadap keragaman fenotip kultivar jagung lokal dan dilanjutkan dengan uji perbandingan berganda Duncan pada taraf signifikansi 0.05. Analisis varian dan uji lanjutan dilakukan dengan program statistica analytical system (SAS versi 9.0). Untuk mengetahui karakter yang memberikan kontribusi paling besar terhadap keragaman fenotip kultivar dan varietas jagung, dilakukan analisis komponen utama. Untuk mengetahui kekerabatan di antara kultivar jagung berdasarkan karakter fenotip, dilakukan analisis gerombol (analisis cluster) dengan metode hirarki. Analisis komponen utama dan analisis gerombol dilakukan menggunakan program komputer SPSS versi 18.0.

\section{HASIL DAN PEMBAHASAN}

Hasil analisis varian (tabel 1) menunjukan bahwa kultivar jagung memberikan pengaruh yang nyata terhadap semua karakter fenotip yang diamati. Hasil pengukuran karakter fenotip yang meliputi karakter pertumbuhan, fisiologi, anatomi, dan hasil kultivar jagung menunjukan nilai rata-rata yang beragam diantara kultivar jagung (tabel 2).

Adanya pengaruh nyata kultivar jagung terhadap keragaman karakter-karakter fenotip yang diamati, diduga terjadi karena perbedaan susunan genetik di antara kultivar dan varietas jagung. Ini sesuai dengan yang dikemukakan oleh Roy (2000) bahwa penampilan fenotip suatu tanaman ditentukan oleh faktor genetik, faktor lingkungan dan interaksi antara keduanya. Dengan demikian, dapat dikatakan bahwa kultivar-kultivar jagung lokal yang ada di Pulau Kisar yang selama ini dibudidayakan oleh petani, memiliki perbedaan dalam susunan genetiknya. Perbedaan susunan genetik ini diekspresikan ke dalam bentuk fenotip yang berbeda, sehingga ketika ditanam pada kondisi lingkungan yang sama, kultivar-kultivar ini memberikan penampilan fenotip yang berbeda-beda.

Hasil analisis komponen utama menunjukkan bahwa terbentuk tiga komponen utama dengan nilai Eigen yang memiliki skor lebih dari satu. Simamora (2005) menyatakan bahwa komponen dengan nilai Eigen kurang dari satu tidak dapat digunakan karena tidak valid dalam 
menghitung faktor yang terbentuk. Haydar et al. (2007) menyatakan bahwa karakterkarakter yang memiliki nilai Eigen terbesar dan positif, merupakan karakter yang berkontribusi maksimum terhadap keragaman dari kultivar-kultivar yang diuji. Komponen utama pertama dengan nilai Eigen 8.502 (varian sebesar $60.72 \%$ ), komponen utama kedua memiliki nilai Eigen 2.879 (varian sebesar 20.56\%), dan komponen utama ketiga memiliki nilai Eigen 1.282 (varian sebesar 9.15). Ketiga komponen utama ini akan mampu menjelaskan keragaman data fenotip kultivar-kultivar jagung sebesar $90.45 \%$ (Tabel 3).

\section{Tabel 1. Rekapitulasi Hasil Analisis Varian Pengaruh Kultivar Jagung Terhadap Karakter Fenotip.}

\begin{tabular}{|c|c|c|}
\hline $\begin{array}{l}\text { Karakter } \\
\text { Fenotipik }\end{array}$ & Variabel Yang Diamati & $\begin{array}{c}\text { Hasil Analisis } \\
\text { Varian }\end{array}$ \\
\hline & Tinggi tanaman & * \\
\hline Karakter & Jumlah daun & * \\
\hline \multirow[t]{3}{*}{ Pertumbuhan } & Panjang daun & * \\
\hline & Lebar daun & * \\
\hline & Kadar prolin & * \\
\hline \multirow[t]{4}{*}{ Karakter Fisiologi } & Umur berbunga jantan & * \\
\hline & Umur berbunga betina & * \\
\hline & Anthesis-silking interval & * \\
\hline & Jumlah stomata & * \\
\hline \multirow{3}{*}{$\begin{array}{c}\text { Karakter anatomi } \\
\text { daun }\end{array}$} & Indeks stomata & * \\
\hline & Kerapatan stomata & * \\
\hline & Panjang porus & * \\
\hline \multirow[t]{10}{*}{ Karakter hasil } & Bobot tongkol tanpa kelobot saat panen & * \\
\hline & Bobot tongkol tanpa kelobot kering udara & * \\
\hline & Bobot tongkol tanpa kelobot kering oven & * \\
\hline & Kadar air tongkol tanpa kelobot saat panen & * \\
\hline & Bobot tongkol tanpa kelobot pada kadar air $12 \%$ & * \\
\hline & Diameter tongkol & * \\
\hline & Panjang tongkol & * \\
\hline & Jumlah baris biji/tongkol & * \\
\hline & Jumlah biji/tongkol & * \\
\hline & Hasil tongkol pada kadar air $12 \%$ (ton/ha) & * \\
\hline
\end{tabular}

*: pengaruh nyata pada $\alpha 0.05$

Nilai akar cirri atau nilai loading (Tabel 4) menunjukkan karakter-karakter yang menyusun komponen. Karakter yang dipilih adalah karakter yang memiliki nilai akar ciri $>0.7$ (Dewi et al. 2009). Berdasarkan nilai akar ciri tersebut, dapat diketahui karakter yang berkontribusi terhadap keragaman yang menyusun komponen utama pertama adalah kadar prolin, bobot tongkol tanpa kelobot saat panen, bobot tongkol tanpa kelobot kering udara, bobot tongkol tanpa kelobot kering oven, bobot tongkol pada kadar air $12 \%$, hasil tongkol tanpa kelobot pada kadar air 12\%, diameter tongkol, jumlah biji per tongkol, dan jumlah baris biji per tongkol. Karakter yang berkontribusi terhadap keragaman yang menyusun komponen utama kedua dan ketiga masingmasing adalah jumlah daun, dan panjang daun (Tabel 4). Effendi dkk. (2010) menyatakan bahwa tujuan dari analisis komponen utama adalah untuk memilih genotip berdasarkan lebih sedikit variabel yang dapat menggambarkan keragaman fenotip dari kultivar-kultivar yang diteliti. 
Biopendix, Volume 3, Nomor 1, Oktober 2016, hlm. 18-27

Tabel 2. Rata-Rata Hasil Pengukuran Karakter Fenotip Kultivar Jagung Lokal dari Pulau Kisar Kabupaten Maluku Barat Daya Provinsi Maluku.

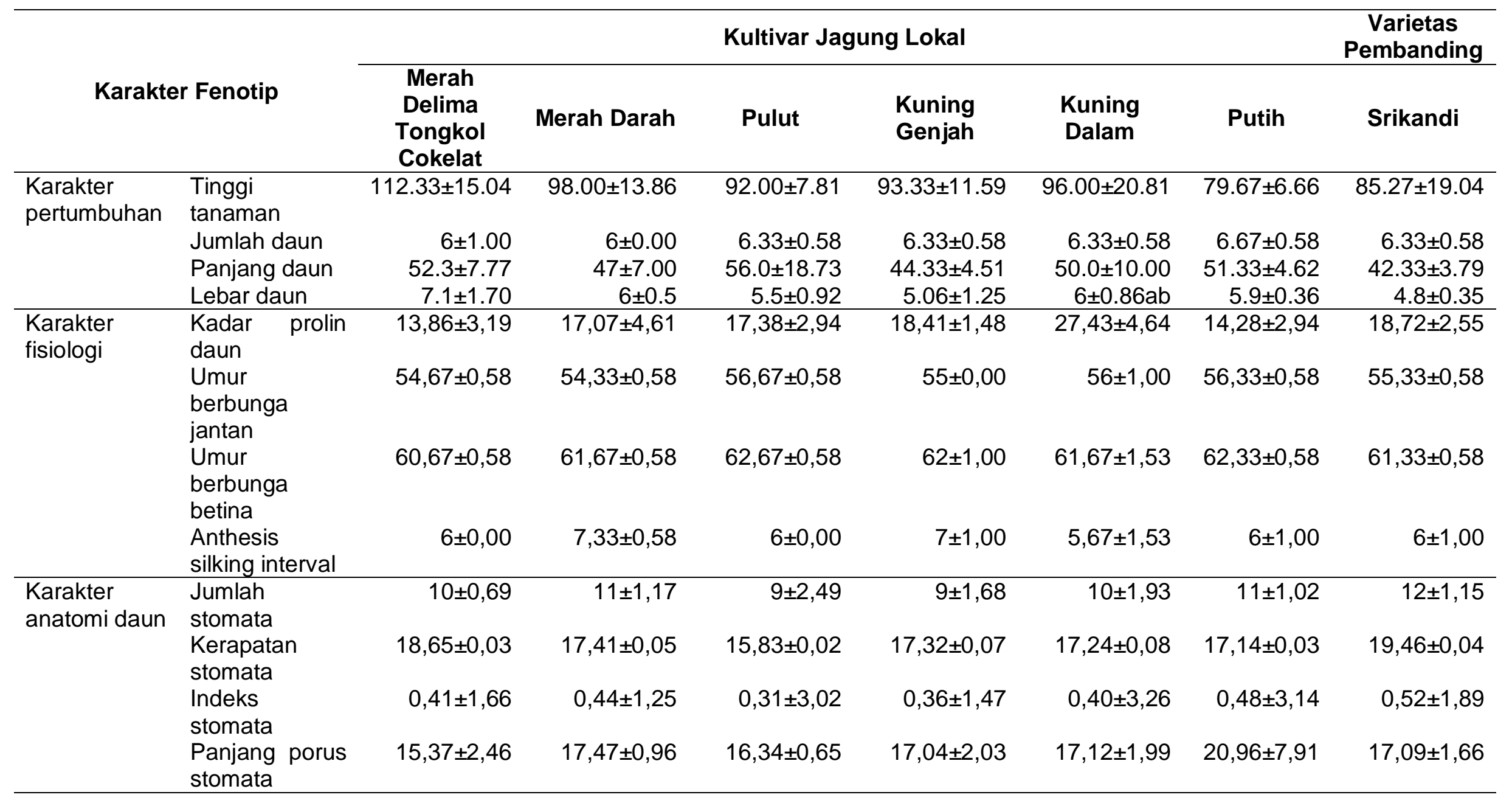


Biopendix, Volume 3, Nomor 1, Oktober 2016, hlm. 18-27

\begin{tabular}{|c|c|c|c|c|c|c|c|c|}
\hline \multirow[t]{12}{*}{$\begin{array}{l}\text { Karakter } \\
\text { hasil }\end{array}$} & $\begin{array}{l}\text { Bobot tongkol } \\
\text { tanpa kelobot } \\
\text { saat panen }(\mathrm{g})\end{array}$ & $73,45 \pm 4,71$ & $46,75 \pm 3,73$ & $67,15 \pm 9,04$ & $85,62 \pm 6,72$ & $128,02 \pm 24,08$ & $88,33 \pm 7,32$ & $69,60 \pm 14,74$ \\
\hline & $\begin{array}{l}\text { Bobot tongkol } \\
\text { tanpa kelobot } \\
\text { setelah kering } \\
\text { udara (g) } \\
\text { Bobot tongkol }\end{array}$ & $70,36 \pm 4,76$ & $44,58 \pm 4,92$ & $64,12 \pm 7,68$ & $80,76 \pm 6,41$ & $122,50 \pm 23,28$ & $85,50 \pm 7,23$ & $66,52 \pm 18,67$ \\
\hline & $\begin{array}{l}\text { tanpa kelobot } \\
\text { kering oven }(\mathrm{g})\end{array}$ & $59,25 \pm 4,13$ & $38,15 \pm 3,34$ & $50,95 \pm 8,67$ & $68,66 \pm 5,16$ & $104,13 \pm 20,54$ & $70,92 \pm 4,91$ & $56,06 \pm 11,82$ \\
\hline & $\begin{array}{lr}\text { Kadar } & \text { air } \\
\text { tongkol } & \text { tanpa }\end{array}$ & & & & & & & \\
\hline & $\begin{array}{l}\text { kelobot saat } \\
\text { panen (\%) }\end{array}$ & $19,43 \pm 0,49$ & $19,49 \pm 0,71$ & $19,44 \pm 0,08$ & $19,77 \pm 0,28$ & $19,52 \pm 0,82$ & $19,66 \pm 1,18$ & $19,46 \pm 0,80$ \\
\hline & $\begin{array}{l}\text { Bobot tongkol } \\
\text { tanpa kelobot }\end{array}$ & & & & & & & \\
\hline & $\begin{array}{l}\text { pada kadar air } \\
12 \%(\mathrm{~g})\end{array}$ & $67,33 \pm 4,69$ & $42,67 \pm 3,68$ & $61,47 \pm 8,29$ & $77,46 \pm 6,22$ & $117,03 \pm 21,69$ & $80,64 \pm 5,65$ & $62,31 \pm 16,49$ \\
\hline & $\begin{array}{l}\text { Hasil tongkol } \\
\text { pada kadar air } \\
12 \% \text { (ton/ha) }\end{array}$ & $0,30 \pm 0,02$ & $0,18 \pm 0,02$ & $0,27 \pm 0,04$ & $0,35 \pm 0,02$ & $0,53 \pm 0,09$ & $0,36 \pm 0,03$ & $0,28 \pm 0,06$ \\
\hline & $\begin{array}{l}\text { Panjang } \\
\text { tongkol tanpa } \\
\text { kelobot }(\mathrm{mm})\end{array}$ & $86,86 \pm 0,85$ & $73,41 \pm 1,05$ & $94,31 \pm 8,55$ & $110,02 \pm 2,83$ & $116,11 \pm 2,67$ & $103,63 \pm 10,91$ & $98,70 \pm 8,89$ \\
\hline & $\begin{array}{l}\text { Diameter } \\
\text { tongkol tanpa } \\
\text { kelobot (mm) }\end{array}$ & $31,00 \pm 4,13$ & $30,11 \pm 1,83$ & $31,72 \pm 1,15$ & $34,86 \pm 3,27$ & $38,09 \pm 1,82$ & $35,40 \pm 0,60$ & $33,21 \pm 1,19$ \\
\hline & $\begin{array}{l}\text { Jumlah biji per } \\
\text { tongkol (biji) }\end{array}$ & $242,33 \pm 44,71$ & $185,56 \pm 16,20$ & $205,00 \pm 16,34$ & $243,56 \pm 50,02$ & $341,56 \pm 37,60$ & $247,67 \pm 23,76$ & $203,44 \pm 46,74$ \\
\hline & $\begin{array}{l}\text { Jumlah baris } \\
\text { biji per tongkol } \\
\text { (baris) }\end{array}$ & $10,89 \pm 0,19$ & $10,66 \pm 0,87$ & $11,11 \pm 0,50$ & $10,33 \pm 0,57$ & $14,11 \pm 0,69$ & $11,66 \pm 0,33$ & $10,78 \pm 1,07$ \\
\hline
\end{tabular}


Biopendix, Volume 3, Nomor 1, Oktober 2016, hlm. 18-27

Tabel 3. Nilai Eigen dan Proporsi Keragaman Masing-Masing Komponen Utama Terhadap Keragaman Total.

\begin{tabular}{crrr}
\hline Komponen & \multicolumn{3}{c}{$\begin{array}{c}\text { Nilai Eigen } \\
\text { \% keragaman }\end{array}$} \\
\hline 1 & \multicolumn{1}{c}{ Total } & 60.728 & \multicolumn{1}{c}{ Kumulatif } \\
2 & $\mathbf{8 . 5 0 2}$ & 20.565 & 60.728 \\
3 & $\mathbf{2 . 8 7 9}$ & 9.156 & 81.294 \\
4 & $\mathbf{1 . 2 8 2}$ & 6.582 & 90.450 \\
5 & .922 & 1.837 & 97.032 \\
6 & .257 & 1.131 & 98.869 \\
7 & .158 & $6.158 \mathrm{E}-15$ & 100.000 \\
8 & $8.622 \mathrm{E}-16$ & $1.697 \mathrm{E}-15$ & 100.000 \\
9 & $2.376 \mathrm{E}-16$ & $8.392 \mathrm{E}-16$ & 100.000 \\
10 & $1.175 \mathrm{E}-16$ & $4.678 \mathrm{E}-16$ & 100.000 \\
11 & $6.549 \mathrm{E}-17$ & $-8.471 \mathrm{E}-16$ & 100.000 \\
12 & $-1.186 \mathrm{E}-16$ & $-1.166 \mathrm{E}-15$ & 100.000 \\
13 & $-1.633 \mathrm{E}-16$ & $-2.669 \mathrm{E}-15$ & 100.000 \\
14 & $-3.736 \mathrm{E}-16$ & $-3.559 \mathrm{E}-15$ & 100.000 \\
& $-4.983 \mathrm{E}-16$ & & 100.000 \\
\hline
\end{tabular}

Tabel 4. Nilai Akar Ciri (Nilai Loading) dari Masing-Masing Komponen Utama

\begin{tabular}{|c|c|c|c|}
\hline \multirow[t]{2}{*}{ Variabel } & \multicolumn{3}{|c|}{$\begin{array}{l}\text { Komponen } \\
\text { Nilai loading }\end{array}$} \\
\hline & 1 & 2 & 3 \\
\hline Tinggi tanaman & .014 & -.612 & .168 \\
\hline Jumlah daun & .297 & .931 & .154 \\
\hline Panjang daun & .080 & -.119 & .916 \\
\hline Lebar daun & .105 & -.613 & .681 \\
\hline Kadar prolin daun & .800 & -.126 & -.420 \\
\hline $\begin{array}{l}\text { Bobot tongkol tanpa kelobot } \\
\text { saat panen }\end{array}$ & .978 & .171 & .051 \\
\hline $\begin{array}{l}\text { Bobot tongkol tanpa kelobot } \\
\text { kering udara }\end{array}$ & .977 & .177 & .068 \\
\hline $\begin{array}{l}\text { Bobot tongkol tanpa kelobot } \\
\text { kering oven }\end{array}$ & .982 & .150 & .026 \\
\hline $\begin{array}{l}\text { Kadar air tongkol tanpa kelobot } \\
\text { sat panen }\end{array}$ & .177 & .651 & -.217 \\
\hline $\begin{array}{l}\text { Bobot tongkol tanpa kelobot } \\
\text { pada kadar air } 12 \%\end{array}$ & .980 & .162 & .071 \\
\hline $\begin{array}{l}\text { Hasil tongkol pada kadar air } \\
12 \%\end{array}$ & .977 & .167 & .057 \\
\hline Diameter tongkol & .901 & .415 & -.120 \\
\hline Jumlah biji per tongkol & .990 & .014 & .082 \\
\hline Jumlah baris biji per tongkol & .904 & -.054 & .172 \\
\hline
\end{tabular}

Hasil analisis gerombol yang dilakukan berdasarkan 22 karakter fenotipik mengelompokkan kultivar jagung ke dalam dua kelompok (gambar 1). Kelompok 1 meliputi kultivar lokal Merah Delima Tongkol Cokelat, Merah Darah, Kuning Genjah, Putih, varietas pembanding Srikandi, dan kultivar 
lokal Pulut, sedangkan kluster 2 hanya satu kultivar yaitu kultivar lokal Kuning Dalam.

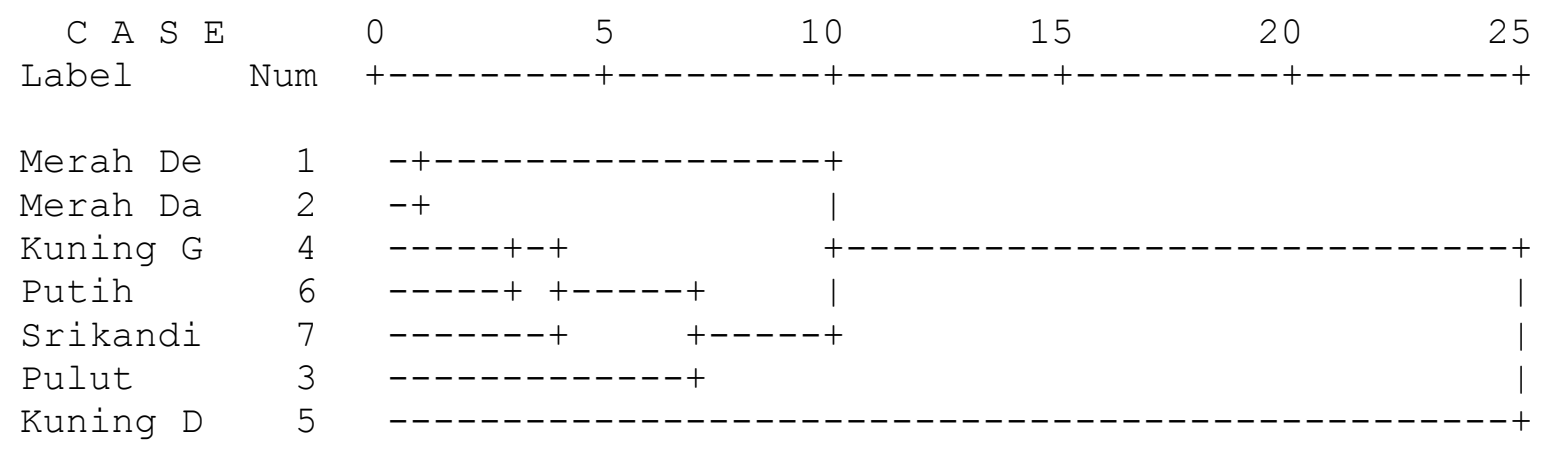

\section{Gambar 1. Pengelompokkan Kultivar Jagung Lokal dari Pulau Kisar dan Varietas Pembanding Srikandi Berdasarkan Karakter Fenotip.}

Kultivar lokal Kuning Dalam berada pada satu kelompok tersendiri, karena hasil pengukuran karakter fenotip khususnya karakter hasil (Tabel 2) menunjukkan kultivar ini memiliki nilai yang berbeda dan lebih tinggi dari kultivar lokal yang lain. Namun demikian, pada karakter fenotip lain seperti pertumbuhan, anatomi, dan fisiologi nilai kultivar ini tidak lebih tinggi dari kultivar lokal yang lain. Dengan demikian, dapat dikatakan bahwa pengelompokan pada Gambar 1 lebih dipengaruhi oleh karakter hasil. Kultivarkultivar lokal yang lain serta varietas pembanding Srikandi cenderung berada dalam kelompok yang sama, karena nilai pengukuran karakter fenotip dari kultivarkutivar dan vaietas tersebut tidak menunjukkan adanya perbedaan yang besar.
Karuwal (2014) juga melakukan karakterisasi morfologi dan scoring data biner 0/1 terhadap 60 karakter morfologi batang, daun, bunga, buah, dan biji dari tujuh kultivar jagung lokal di Pulau Kisar menggunakan program NTSYS dan menemukan bahwa terbentuk dua klaster utama di mana kultivar kuning Dalam juga berada pada satu klaster tersendiri dan terpisah dari kultivar lokal yang lain.

Pengelompokkan berdasarkan nilai jarak Euclidean berkisar antara 23.73 - 104.37 (Tabel 5). Jarak Euclidean menunjukan jarak antara satu kultivar dengan kultivar yang lain, Semakin kecil jarak Euclidean, semakin dekat atau semakin mirip suatu kultivar dengan kultivar yang lain. 
Biopendix, Volume 3, Nomor 1, Oktober 2016, hlm. 18-27

Tabel 5. Nilai Jarak Euclidean Antar Kultivar Jagung Lokal dan Varietas Pembanding Srikandi.

\begin{tabular}{|c|c|c|c|c|c|c|c|}
\hline \multirow[b]{2}{*}{ Kultivar } & \multicolumn{7}{|c|}{ Squared Euclidean Distance } \\
\hline & $\begin{array}{c}\text { Merah } \\
\text { Delima } \\
\text { Tongkol } \\
\text { Cokelat }\end{array}$ & $\begin{array}{l}\text { Merah } \\
\text { Darah }\end{array}$ & Pulut & $\begin{array}{l}\text { Kuning } \\
\text { Genjah }\end{array}$ & $\begin{array}{l}\text { Kuning } \\
\text { Dalam }\end{array}$ & Putih & Srikandi \\
\hline $\begin{array}{l}\text { Merah } \\
\text { Delima } \\
\text { Tongkol } \\
\text { Cokelat }\end{array}$ & .000 & & & & & & \\
\hline Merah Darah & 23.733 & .000 & & & & & \\
\hline Pulut & 35.993 & 33.769 & .000 & & & & \\
\hline $\begin{array}{l}\text { Kuning } \\
\text { Geniah }\end{array}$ & 39.595 & 35.242 & 28.512 & .000 & & & \\
\hline $\begin{array}{l}\text { Kuning } \\
\text { Dalam }\end{array}$ & 68.512 & 104.372 & 64.418 & 46.442 & .000 & & \\
\hline Putih & 54.025 & 53.127 & 33.060 & 27.253 & 44.698 & .000 & \\
\hline Srikandi & 34.322 & 27.624 & 42.658 & 29.956 & 67.116 & 29.572 & .000 \\
\hline
\end{tabular}

Tabel 5 menunjukkan bahwa Kultivar lokal Kuning Dalam memiliki kemiripan yang rendah dan kekerabatan yang jauh dengan semua kultivar lokal dan juga varietas pembanding Srikandi yang didasarkan pada keragaman fenotipnya. Hasil ini sesuai dengan hasil pengukuran karakter fenotip (Tabel 2) dan pengelompokkan pada Gambar 1. Dengan demikian dapat dikatakan bahw kultivar lokal Kuning Dalam memiliki perbedaan dalam hal karakter fenotip dan memiliki hubungan kekerabatan yang rendah dengan kultivar jagung lokal yang lain serta varietas pembanding Srikandi. Sebaliknya, varietas pembanding Srikandi memiliki kemiripan yang dekat dengan kultivar jagung lokal yang lain. Hasil ini menunjukkan bahwa meskipun varietas pembanding Srikandi merupakan varietas yang direkomendasikan sebagai varietas unggul toleran kekeringan, tetapi ketika ditanam pada kondisi lingkungan di Pulau Kisar Kabupaten Maluku Barat Daya, varietas ini menunjukkan kemiripan fenotip yang sama dengan kultivar lokal Merah Delima Tongkol Cokelat, Merah Darah, Pulut, Kuning Genjah, dan Putih dalam hal responnya terhadap lingkungan.

\section{KESIMPULAN DAN SARAN}

Terdapat keragaman fenotip kultivarkultivar jagung lokal dan varietas pembanding Srikandi yang ditanam di Pulau Kisar Kabupaten Maluku Barat Daya Provinsi Maluku. Karakter yang berkontribusi besar terhadap keragaman fenotip adalah kadar prolin, bobot tongkol tanpa kelobot saat panen, bobot tongkol tanpa kelobot kering udara, bobot tongkol tanpa kelobot kering oven, bobot tongkol pada kadar air $12 \%$, hasil tongkol tanpa kelobot pada kadar air $12 \%$, diameter tongkol, jumlah biji per tongkol, jumlah baris biji per tongkol, jumlah daun, dan panjang daun. Hasil analisis gerombol dan jarak Euclidean menunjukkan bahwa kultivar lokal Kuning Dalam berada pada satu kelompok sendiri dan memiliki kemiripan yang rendah dengan kultivar jagung lokal yang lain serta varietas pembanding Srikandi berdasarkan pada karakter fenotipnya. 


\section{DAFTAR PUSTAKA}

Alfons, J.B., M. Pesireron., A.J. Rieuwpassa., R.E. Senewe., \& F. Watkaat. 2003. Pengkajian Peningkatan Produktivitas Tanaman Pangan Tradisional di Maluku. Laporan Tahunan 2003. Ambon: Balai Pengkajan Teknologi Pertanian Maluku.

Amzeri, A., D. Indradewa., B. S. Daryono., \& D. Rachmawati. 2011. Kekerabatan Jagung (Zea mays L.) Lokal Madura Berdasarkan Karakter Morfologi dan Penanda RAPD. Biota 16 (2): 227-235

Dewi, I.S., A.S. Trilaksana., T. Koesoemaningtyas., \& B.S. Purwoko. 2009. Karakterisasi Galur haploid ganda hasil kultur antera padi. Buletin Plasma Nutfah, 15(1): 1-12.

Efendi, R., Suwardi., \& M. Isnaini. 2010. Metode dan penentuan karakter seleksi genotype jagung terhadap cekaman kekeringan pada fase awal vegetative. Prosiding Pekan Serealia Nasional, 2010. ISBN: 978-979-8940-29-3

Febriani, Y., S. Ruswandi., M. Rachmady., \& D. Ruswandi. 2008. Keragaman GalurGalur Murni Elit Baru Jagung Unpad di Jatinangor-Indonesia. Zuriat 19 (1): 104-115

Haydar, A., M.B. Ahmed., M.M. Hannan., M.A. Razvy., M.A.Mandal., M. Salihin., R. Karim., M. Hossain. 2007. Analysis of genetic diversity in some potato varieties grown in Bangladesh. Middle East Journal of Science Research, 2: 143145.

Karuwal, R. 2014. Keragaman Genetik Kultivar Jagung Lokal Dari Pulau Kisar Maluku Berdasarkan Karakterisasi Morfologis. Prosiding Seminar Nasional Insentif Ristek Sinas. Kementerian Riset dan Teknologi. Bandung, 1-2 Oktober 2014.

Pabendon, M.B., M. Azrai., M.J. Mejaya., \& Sutrisno. 2008. Keragaman Genetik Inbrida Jagung QPM dan Normal Berbasis Marka Mikrosatelit dan Hubungannya dengan Penampilan Hibrida. Jurnal AgroBiogen 4 (2): 77-8

Pesireron, M., M. P. Sirappa., \& La Dahamarudin. 2013a. Keragaman
Genetik Jagung Lokal Di Kabupaten Maluku Barat Daya, Provinsi Maluku. Seminar Nasional Serealia, 2013: 85-97

Pesireron, M., M. P. Sirappa., \& La Dahamarudin. 2013b. Keragaman Genetik Jagung Lokal Di Kecamatan Leti Dan Pulau-Pulau Terselatan, Kabupaten Maluku Barat Daya, Provinsi Maluku. Seminar Nasional Serealia, 2013: 92 104

Roy, D. 2000. Plant Breeding, analysis and exploitation of variation. Narosa Publishing House. New Delhi. 701 hal.

Simamora, B. 2005. Analisis Multivariat Pemasaran. Jakarta: PT. Gramedia Pustaka Utama.

Susantidiana, W.A., B. Lakitan., \& M. Surahman. 2009. Identifikasi beberapa jarak pagar (Jatropha curcas L.) melalui analisis RAPD dan morfologi. Jurnal Agronomi, 37 (2): 167-173.

Wijayanto, T. 2007. Karakterisasi Sifat - Sifat Agronomi Beberapa Nomor Koleksi Sumber Daya Genetik Jagung Sulawesi. Jurnal Penelitian dan Informasi Pertanian 11 (2): 75-83. 